\title{
The ILO's Role in Global Governance: Limits and Potential
}

\author{
Velibor Jakovleski, Scott Jerbi and Thomas Biersteker
}

\begin{abstract}
The International Labour Organization (ILO) has demonstrated a remarkable ability to adapt to changing conditions throughout its long history. At its centenary, the ILO must once again respond to evolving circumstances and find new ways to engage state and private actors participating in an interconnected global economy where labour standards continue to be violated and where work itself is undergoing significant transformations. This chapter explores recent efforts by the ILO's leadership to reassert the organisation's role in broader global policy contexts. Part 1 presents the concept of institutional layering in order to understand better the agents of change and the structures in which they operate. The three sections that follow demonstrate institutional layering across three core dimensions of global governance-actors, rules, and mechanisms - in the period since 1998. The chapter concludes that the ILO's current governance practices have mixed prospects for the organisation's role in a changing governance landscape. New layers of soft law rules and flexible governance mechanisms can potentially augment the ILo's global standing moving forward. Its lack of representativeness and its continuing engagement of new actors, however, demand further formal changes to the ILO's institutional apparatus.
\end{abstract}

\section{$1 \quad$ Introduction}

Over its long history, the International Labour Organization (ILO) has been at the forefront of global debates on social justice and the world of work. It was established in 1919 at a time when frictions between business and labour, the so-called labour problem, were widespread (Helfer, 2006). The ILO's golden age could be said to have culminated in 1969 with the awarding of a Nobel Peace Prize to the Organization fifty years after its foundation. ${ }^{1}$ Thereafter,

1 See the website https://www.nobelprize.org/nobel_prizes/peace/laureates/1969/labour-facts .html (accessed on 12 June 2018).

(C) VELIBOR JAKOVLESKI ET AL. 2019 | DOI:10.1163/9789004399013_006

This is an open access chapter distributed under the terms of the prevailing CC-BY-NC license at the time of publication. 
global economic and ideational changes began to challenge some of the ILO's core norms. Globalisation, understood as the worldwide intensification of socio-economic interdependence, the deepening integration of local and national activities into the global economy, and modes of thinking shifting away from the national level towards regional and global levels (Biersteker, 1998), presented a new set of policy problems and priorities and increased pressure on the ILO's foundational structure to adapt.

The extent to which the ILo has met those challenges as well as its role in contemporary global governance has been questioned. Some observers suggest the Organization is increasingly at the margins of influence of global economic governance (Weiss, 2011). Critiques of the ILO centre on its declining standard-setting role (see Figure 5.1, below), low ratification rates of its conventions (Boockmann, 2001), perceived non-representativeness (Alston, 2005), overambitious mandate (Standing, 2008, 2010) and restrictive decision-making processes (Baccaro and Mele, 2012). Recent decades have also seen the emergence of new and diverse governance arrangements and actors outside ILO structures that are also addressing, or potentially undermining, the protection of worker rights.

Despite these criticisms and in an effort to contribute to the debate about the ILO's changing role in global governance at its centenary, this chapter assesses recent efforts by the ILo's leadership to augment the organisation's influence in a number of critical policy domains. The analysis provides a historical institutionalist argument to explain the sources and nature of those reform initiatives-largely driven by different Directors General and sometimes developed outside the ILO - which at times are also supported by governments and employer and worker groups. Part one of the chapter introduces the concept of institutional layering in order to understand why the ILO has adapted incrementally. The three sections that follow demonstrate layering across three core dimensions of global governance-actors, rules, and mechanismsfocusing on the period since 1998. Evidence suggests that the ILO has: (1) shifted in the area of standard-setting towards soft law instruments to promote respect for labour rights rather than an exclusive focus on traditional international legal instruments; (2) developed, with respect to implementation and capacity building, partnerships with multiple and diverse actors beyond action undertaken exclusively within its tripartite structure; and (3) opened itself to the role of decentralised governance mechanisms and self-regulation in addition to more traditional regulation of labour through state-based steering mechanisms. Those changes have significant implications for the organisation's global governance role. While emphasising soft and flexible instruments and involvement in decentralised governance can potentially augment its global 
governance role moving forward, the ILO's engagement of new actors will demand further changes to its formal institutional apparatus to be effective.

\section{Governance in Layers: The ILO's Gradual Adaptation to a Changing Global Context}

Global governance is defined here as 'an inter-subjectively recognized, purposive order at the global level, which defines, constrains, and shapes actor expectations in an issue domain' (Biersteker, 2015, 160). It is based on systems of authoritative rules (both formal and informal) that apply to multiple actors (both public and private) whose behaviours are coordinated by governance mechanisms (ranging from hierarchy and steering by an agent to self-regulation by a market) to achieve particular objectives (Biersteker, 2015).

We argue that the ILO's efforts over the past two decades to (re)assert its role in global governance entail a process of incremental change to the rules, actors, and mechanisms of governance. Why has change been gradual and often at the margins, despite growing concerns that the ILo's global standing has itself been in decline? Even during periods of major change (e.g. wars, global economic crises, the changes brought on by globalisation) significant organisational change does not come about easily. External factors alone are not sufficient to inform change because certain institutional actors must have the incentives and ability to do so (Andonova, 2017).

The ILO's institutional apparatus was established in 1919 and it initially empowered a specific constellation of actors-governments, unions and employers-within a tripartite structure that was revolutionary at the time. Those same actors operate essentially by the same rules today, demonstrating that institutions can persist long after the constellation of interests and actors that initially gave rise to them have changed (Pierson, 2004). The ILO's evolution has thus been shaped by a predictable dynamic whereby the tripartite actors have been incentivised to perpetuate the institutional status quo and to consolidate further their positions, while resisting changes that challenge their privileged positions (Mahoney, 200o). Conversely, changes that could diverge notably from the status quo often originate from relatively weaker actors institutionally, such as the Director General and Secretariat, or external change agents such as civil society or corporations.

Under conditions where actors are either unwilling (e.g. the tripartite actors) or formally unable (e.g. the International Labour Office) to undertake significant change, the ILO's recent reform efforts are examples of what historical institutionalists call 'institutional layering' (Mahoney and Thelen, 2010). 
Layering does not alter the formal institutional framework of an organisation, which continues to enjoy at least a modicum of legitimacy. It is a conservative way to go about organisational change and includes new practices being appended to existing institutions. As a result, the institutionally privileged tripartite actors can tolerate deviations from the status quo and even abide by some new practices. If the new governance layers are perceived to threaten their privileged positions, however, the tripartite actors can fall back to the ILO's existing institutional framework and reinforce their positions formally.

Institutional layering can take the form of new rules or policy processes, the addition of new actors, or the introduction of new mechanisms of governance, as the following three sections will demonstrate, respectively. Crucially, the institutional layers do not replicate the ILO's existing formal structures, which specify a well-defined set of actors interacting largely through formal governance mechanisms. The new layers include 'soft' rules, engagements with a multiplicity of new actors, and more decentralised mechanisms for regulating their behaviours. Thus, layering opens the door for other actors, rules, and processes to contest the authority of the ILO and its social partners in the implementation and development of global labour standards. How that contestation is managed will have implications for the ILo's global governance role moving forward.

\section{3}

\section{The ILO's Increasing Reliance on 'Soft' Governance}

Historically praised for its formal standard-setting activities, the nature of the ILO's outputs and the extent to which they are authoritative has evolved significantly over recent decades. The ILO (like many other international organisations) has increasingly relied on 'soft' governance instruments as opposed to legally binding standards (Vabulas and Snidal, 2013). The ILO's Recommendations, Declarations, and overarching policy frameworks are examples of instruments that move away from traditional forms of legal authority. They are characterised by relatively lower degrees of obligation, precision and delegation (Abbott et al., 2000) and help overcome practical problems like the inability to reach broad acceptance of legally binding commitments and their associated high political costs. For critics, however, such instruments represent a weakening of legally binding commitments and a dangerous turn to more aspirational and promotional approaches to achieving broader progress in labour rights protection. ${ }^{2}$

2 For a helpful summary of debates around the Declarations, see Hughes and Haworth (2011). 


\subsection{Promoting Labour Standards through Recommendations}

During the mid-1990s, a period during which its formal standard-setting role was in decline (Figure 5.1), soft law instruments were viewed as a means by which to breathe new life into the ILO. At that time, the tripartite constituents were largely content with the status quo: workers were unwavering supporters of the adoption of conventions as opposed to recommendations-despite their obviously declining ratification rates — while employers' groups supported conventions at least implicitly (ILO, 1997a).

Director General Michel Hansenne, who headed the organisation through the 1990s, thought other approaches could be more strategic and called for more frequent use of recommendations. Specifically, he advocated that recommendations serve as autonomous instruments, rather than simply as supplements to elaborate conventions, as was the norm (ILO, 1997a). The idea of promoting recommendations separately from conventions would not challenge the institutional status quo, as Hansenne tried to assure his constituents: 'The ILO does not need to move away from its constitutional framework or

\section{Conventions,}

Recommendations

Declarations

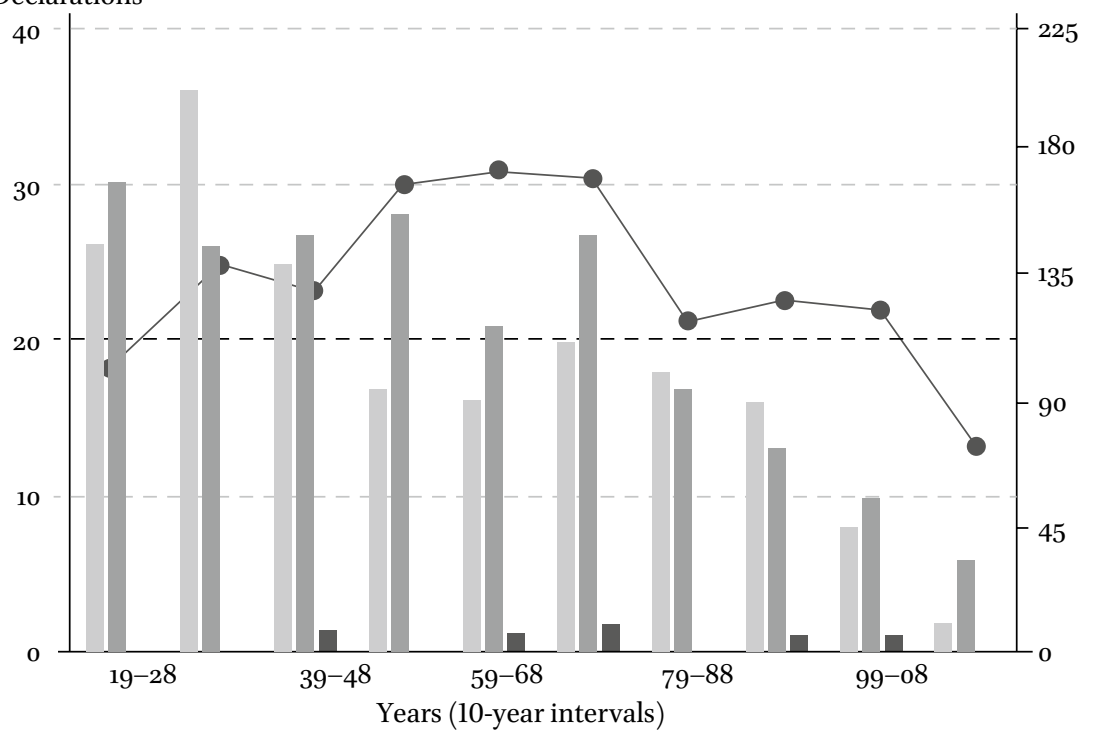

Conventions 
even to change it in order to be able to take on any new standard-setting activities it might assume in this age of globalization. All it has to do is to make a more judicious use -- more in line with their original objectives -- of the unique means of action [i.e. Recommendations] placed at its disposal' (ILO, 1997a).

Since 1998, the ILO's formal outputs include nine conventions, two of which were protocols to existing conventions. The ILo's most recent convention-the 2011 Domestic Workers Convention ${ }^{3}$ - was of a technical nature, rather than a priority 'governance' or 'fundamental' convention. With only 25 ratifications at the time of writing, this convention entered into force in 2013 and signals the declining relevance of 'hard law' instruments issued by the ILO.

During the same period, the ILO has adopted 17 additional soft instruments in the form of recommendations. Notably, over half of those recommendations ( 9 out of 17) can be classified as 'autonomous' instruments, meaning they were not adopted to simply provide precision to the terms of a corresponding convention. Rather they address new issues by providing guidance through authoritative statements on certain principles, and can shape policies and generate legal effects at the national level. Autonomous resolutions indicate a trend towards greater reliance on less formal instruments that can build on the formal institutional framework already in place. A recent example is the 2015 Transition from the Informal to the Formal Economy Recommendation, ${ }^{4}$ which was adopted nearly unanimously. It was anticipated that the Recommendation would help address a 'major gap in ILO standards' and enhance the global standing of the ILO as a forum for the discussion of good labour practices (ILO, 2012,10).

\subsection{Promoting Labour Standards through Broad Policy Frameworks}

In a similar vein, declarations are another 'soft' instrument that has become important for the ILO in recent decades. The adoption of the 1998 Declaration on Fundamental Principles and Rights at Work ${ }^{5}$ was seen by supporters both as addressing significant shortcomings in the implementation of existing ILO conventions and as solidifying global consensus in a non-legally binding text

3 See Domestic Workers Convention, 2011 (No. 189), available at the website https://www.ilo .org/dyn/normlex/en/f?p=NORMLEXPUB:12100:0::NO::P12100_ILO_CODE:C189 (accessed on 21 August 2018).

4 See Recommendation No. 204 concerning the Transition from the Informal to the Formal Economy, available at the website http://www.ilo.org/wcmsp5/groups/public/---ed_norm/--relconf/documents/meetingdocument/wcms_377774.pdf (accessed on 21 August 2018).

5 See ILO Declaration on Fundamental Principles and Rights at Work, available at the website https://www.ilo.org/declaration/thedeclaration/textdeclaration/lang--en/index.htm (accessed on 21 August 2018). 
around basic workplace rights or 'core labour standards' that apply in all countries. The Declaration was constituted as an expected standard of performance for all states and was also viewed as a framework that could assist in modernising the structure and operations of the ILO.

Like workers' groups, some states preferred to prioritise formal instruments but many others preferred a non-legally binding alternative (ILO, 1997c). ${ }^{6}$ A declaration was seen as a politically cost-effective way for Member States to acknowledge their commitment to core principles, even for those states not ready to ratify the corresponding conventions (ILO, 1997d). Supporting the idea of institutional layering, the Director General assured his constituents that 'it is in no way a question of imposing, through such a declaration, new obligations on member States against their will' (ILO, 1997d). With no new obligations, a declaration would not put into question the existing legal basis of the ILO system nor would it require a constitutional amendment.

In 1999, Juan Somavía began his term as the ILo's ninth Director General by seeking to build on the declaration's foundation and underlying logic as a governance instrument with the Decent Work Agenda (ILO, 1999). As close observers have noted (Rodgers et al., 2009, 223), the idea of 'decent work' reflected a desire to improve ILO coherence internally and signalled a recognition of rapid changes in the nature of work at the end of the twentieth century, changes to which the ILO needed to respond if it wished to maintain its relevance. This was particularly important after the 2008 global financial crisis, which presented an opportunity for the ILO to play an important role in helping coordinate global action for recovery and for fair and sustainable globalisation. Within that context, the Director General envisioned that 'The ILO's Decent Work Agenda can be a foundation for a global new deal' (Somavía, 2008). It was followed up with the 2008 Declaration on Social Justice for a Fair Globalization ${ }^{7}$ and the 2009 Global Jobs Pact, ${ }^{8}$ with the purpose of once again reaffirming existing principles and objectives of the organisation, in this case those set out in the Decent Work Agenda and already contained in the ILo's Constitution.

To recap, since 1998 the ILO has moved steadily towards non-binding standard-setting processes. In addition to nine autonomous recommendations, it has revised a past declaration and adopted two new declarations and

6 GB.270/3/1(Add.) 270th Session, Geneva, November 1997.

7 See ILo Declaration on Social Justice for a Fair Globalization, available at the website http://www.ilo.org/global/meetings-and-events/campaigns/voices-on-social-justice/ WCMS_099766/lang--en/index.htm (accessed on 21 August 2018).

8 See Recovering from the crisis: A Global Jobs Pact, available at the website https://www.ilo .org/ilc/ILCSessions/98thSession/texts/WCMS_115076/lang--en/index.htm (accessed on 21 August 2018). 
developed two broad policy frameworks (the Decent Work Agenda and Global Jobs Pact). These instruments have relatively lower degrees of legal obligation, they have broad objectives, and they rarely delegate significant formal authority. As a result, recommendations, declarations and policy frameworks can increase the breadth of the ILO's regulatory reach, but not necessarily its depth. The incorporation of labour standards in trade agreements, as discussed in the next section, provides an illustration.

\subsection{The Added Value of Soft Instruments? Labour Standards in Trade Agreements}

It should be recalled that the World Trade Organization (wTO) identified the ILO as the competent body to negotiate labour standards at its 1996 Singapore Ministerial Conference, with its refusal to incorporate a so-called social clause within the multilateral trade regime. Both employers and developing countries were against including a punitive social clause in the WTo's Charter because of concerns that it might be leveraged into a form of protectionism (Biffl and Isaac, 2002). There was also considerable resistance within the ILO to setting up what would effectively become a punitive social clause, because it would undermine the ILO's traditional emphasis on technical assistance and moral suasion to promote labour standards (Haworth and Hughes, 1997). Soft instruments were a logical way of overcoming the resistance, allowing trading partners to incorporate some ILO labour standards, without necessarily guaranteeing their strict enforcement.

Between 1993 and 2017, 81 trade agreements (29 per cent overall) included labour provisions. ${ }^{9}$ It is noteworthy that since 2010, a greater than average proportion of bilateral/regional free trade agreements have included references to labour standards (Figure 5.2). When trade agreements make specific reference to ILO standards, the 1998 Declaration is the most frequently referenced instrument, found in around 68 per cent of trade agreements (ILO, 2016b), and the Declaration serves as a labour standards floor in most cases (ILO, 2016a). Others, such as the Social Justice Declaration and the Decent Work Agenda, are also invoked more frequently than legally binding instruments, with the exception of Convention 182 on the Worst Forms of Child Labour. ${ }^{10}$ The ILO's

9 The data are based on an analysis of 279 trade agreements reported to the wTO. Labour provisions take into account: any standards that address labour relations, any mechanisms that promote compliance with the standards set, and any framework for cooperative activities such as dialogue or monitoring.

10 See Worst Forms of Child Labour Convention, 1999 (No. 182), available at the website https://www.ilo.org/dyn/normlex/en/f?p=NORMLEXPUB:12100:0::NO::P1210o_ILO_ CODE:C182 (accessed on 21 August 2018). 


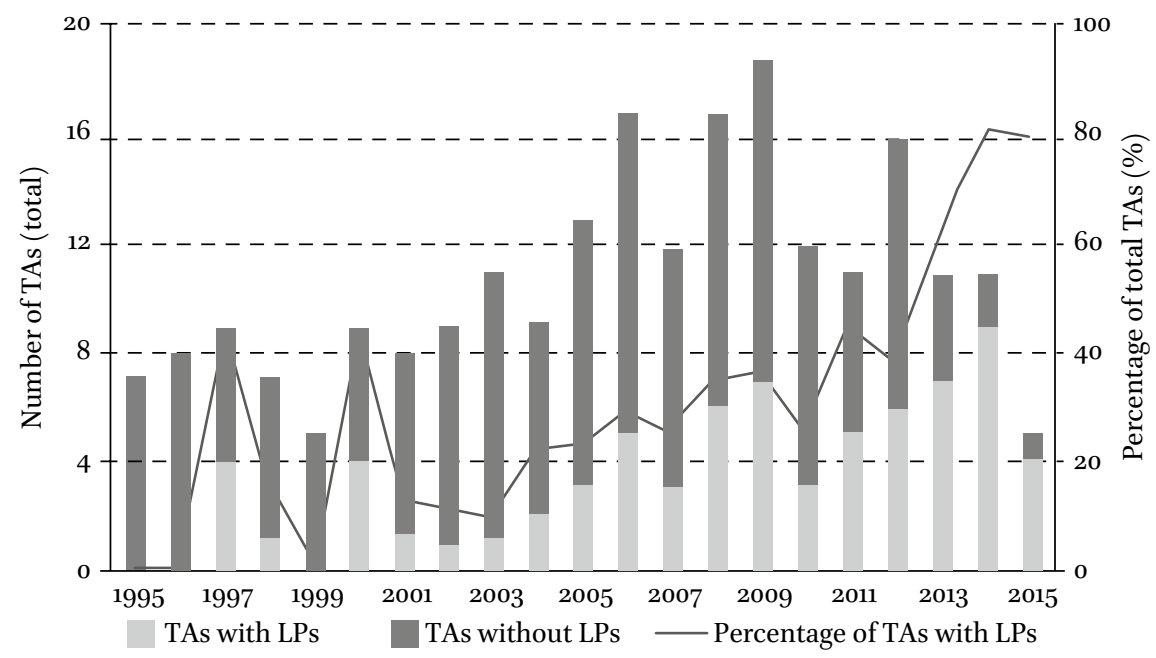

FIGURE 5.2 Proportion of trade agreements with labour provisions, 1993-2017 SOURCE: WTO (2018), AUTHORS' ELABORATION OF DATA.

so-called fundamental conventions are rarely invoked in trade agreements (9.2 per cent) despite the fact that those eight conventions enjoy near universal ratification by Member States (over 91 per cent of all possible ratifications). The discrepancy highlights the significant difference between ratifying conventions (within the ILO) and the eventuality of implementing them, especially within frameworks that can be backed up by formal dispute settlement and sanctions for non-compliance (such as trade agreements). The latter recourse, however, has only rarely been used. A more promotional approach is often used to provide special incentives when partners subscribe to labour standards, rather than punishing them when they fail to do so (ILO, 2016a).

Nevertheless, the ILO's formal processes remain in place and can be invoked - in tandem with the promotion of non-binding standards - when there is sufficient tripartite consensus and political will. A prominent recent example of using the ILO's complaint procedure during the International Labour Conference was the complaint brought against Qatar's violations of the Forced Labour ${ }^{11}$ and Labour Inspection ${ }^{12}$ Conventions. After three years the

11 See Forced Labour Convention, 1930 (No. 29), available at the website http://www.ilo.org/ dyn/normlex/en/f?p=1000:12100:0::NO::P1210o_ILO_CODE:Co29 (accessed on 21 August 2018).

12 See Labour Inspection Convention, 1947 (No. 81), available at the website http://www.ilo .org/dyn/normlex/en/f?p=NORMLEXPUB:12100:0::NO::P1210o_ILO_CODE:Co81 (accessed on 21 August 2018). 
complaint was withdrawn when Qatar's government agreed to implement a three-year ILO technical cooperation programme. Whether such governance by conditionality proves to be a game changer, and the extent to which Qatar will revise its laws to meet international labour standards, remains to be seen. But it could indicate that the ILO's comparative advantage in improving global labour conditions is increasingly tied to its technical cooperation expertise rather than its legally-binding standards setting procedures.

\section{$4 \quad$ Engaging New Actors in Partnerships}

Recognising that 'new international groupings are exercising an influence of increasing importance in the international arena' (ILO, 1998b, para. 52), the ILO has prioritised greater involvement and greater visibility both internationally and at the country level in recent years in order to promote its standards and achieve their progressive implementation. The ILO's approach to engaging with new actors includes both partnership platforms based on strategic bilateral or multilateral engagement with other international organisations and stand-alone public-private partnerships (PPPs) largely focused on implementation (Andonova, 2017). ${ }^{13}$

\subsection{Partnership Platforms and Policy Influence with Other International Organisations}

The ILO has a strong track record of partnering with other international organisations. Since 1946, the ILO has signed 86 partnerships with IOs, with a marked increase during the first decade of the new millennium (Figure 5.3). That trend is more prominent today as part of the ILO's current reform agenda, which seeks to strengthen the organisation's bilateral relationships with other international organisations (ILO, 2013). The partnerships demonstrate that the ILO continues to operate with many traditional and relatively formal arrangements. They also indicate an increasing willingness and recognised need for the ILO to cooperate with other organisations to attain its cross-cutting mandate.

\footnotetext{
13 Partnership platforms are institutional frameworks at the global level that set out broad common goals. To be realised, they require a second tier of collaboration among a multiplicity of actors that then implement the agreements across multiple jurisdictions. PPPS are free-standing individual agreements organised by public and private actors that pursue commonly agreed objectives. Their (non-exclusive) governance functions include: (1) developing norms, standards, or policies, (2) implementation, and (3) information production and dissemination. The governance functions of partnership platforms and PPPS can overlap. See Andonova (2017, 19-20).
} 


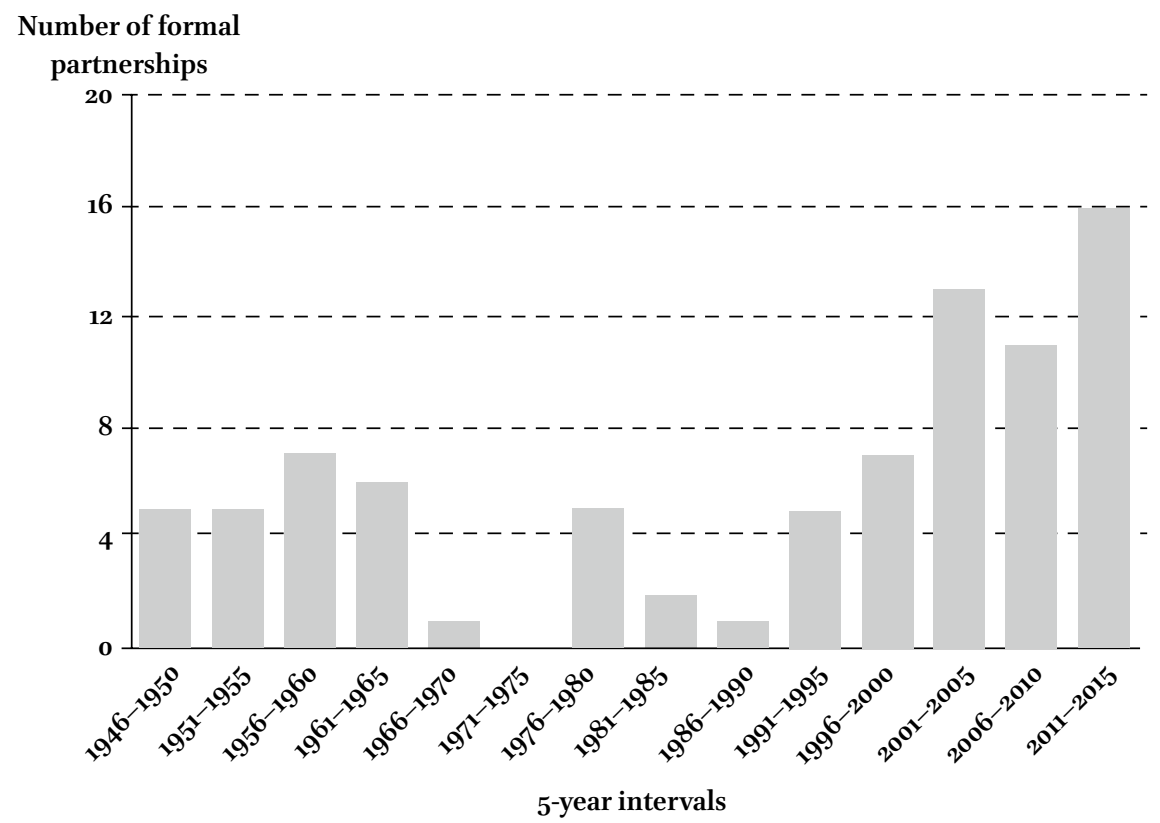

FIGURE 5.3 Bilateral partnerships concluded between the ILO and other international organisations, 1946-2015 SOURCE: ILO (2018e), AUTHORS' ELABORATION OF DATA.

Many other efforts by the ILO in the multilateral arena take the shape of multistakeholder partnership platforms that vary in their degree of formality and institutionalisation. The following is a non-exhaustive list for illustrative purposes. In each case, the ILO's objective is not necessarily to play the main governing function but to create a 'multiplier effect' whereby other organisations take up its standards or integrate concepts such as the 'social protection floor' and 'decent work' into their activities (ILO, 2016c, 27).

The Better Work programme, an initiative of the ILO and the International Finance Corporation (IFC), is one high-profile example of a multi-stakeholder partnership. It began in 2001 around a joint project in Cambodia to improve working conditions in the country's apparel export industry. Today, the Better Work programme is active in eight countries with over 1,400 participating factories. Independent evaluations conclude that the programme has been instrumental in preventing abusive labour practices, limiting excessive overtime and closing gender pay gaps in factories involved. ${ }^{14}$

14 For more information, see Better Work, Progress and Potential: How Better Work is improving garment workers lives and boosting factory competitiveness, A summary of an 
The 2007 Green Jobs Initiative, described by Kees van der Ree in this volume (Chapter 12), provides another example. It was launched as a partnership between the United Nations Environment Programme (UNEP), the International Trade Union Confederation (ITUC) and the International Organisation of Employers (IOE). Subsequent successes for the ILO in terms of integrating its standards into other relevant agreements include the United Nations Framework Convention on Climate Change's (UNFCCC) inclusion of 'decent work' in its shared vision for a future global climate change regime, and the Rio+2o outcome document one year later recognising decent work as a key part of sustainable development. According to van der Ree, both internal factors (e.g. the role of ILO Directors General) and external factors (including growing consensus on the links between climate change and labour issues) contributed to the establishment of the link between decent work and the environment in the ILO's core work.

Another example of partnership platforms is the way the ILO seeks to influence programmes of the International Monetary Fund (IMF) and the World Bank (WB) in low- and middle-income countries. Independent critiques of these programmes conclude that they have been directly at odds with core ILO norms, and that their flexible labour requirements are negatively correlated with labour rights implementation in the countries involved (Blanton et al., 2015). In 1994, the ILO was granted observer status at annual IMF/WB meetings, and observer status at the IMF/WB Development Committees in 1999. Since then, there has been a tempering of some of the World Bank's and IM F's more extreme reform requirements, as well as the inclusion of labour standards in some development loan contracts (Onida, 2008; Anner and Caraway, 2010). Since 2010, the ILO and IMF have also agreed to work together on policies that promote social dialogue, employment-creating growth and a minimum social protection floor for the most vulnerable (Servais and Van Goethem, 2016).

Recent ILO Directors General have also invested considerable resources to promote core labour standards and the Decent Work Agenda in the deliberations and outputs of other global governance fora, with the G2o a notable example. During the period 2008-15, the G20 made some 1,627 commitments ${ }^{15}$ of which 92 were classified as 'employment and labour' commitments

independent assessment of the Better Work programme, 2016, available at the website https://betterwork.org/blog/portfolio/impact-assessment/ (accessed on 17 August 2018).

15 Commitments are the specific passages in documents released publicly that carry the authority of the group of leaders. Commitments must be determined to have enough precision, obligation and future orientation so as to shape the subsequent behaviours of the G2o members in a measurable way. 
(G2o Research Group, 2015). ${ }^{16}$ Among all commitments by the G2o during this period, ILO standards were explicitly invoked on only two occasions. ${ }^{17}$ More often (seven times) the ILO was called on to play a supportive role, in helping implementation, monitoring, and providing information or expertise. ${ }^{18}$ For instance, in response to the G20 calling on the ILO to play a role in examining how to address the social repercussions of the 2008 financial crisis, the ILO strengthened its capacity to monitor and assess crisis response policies (ILO, 2009). Director General Guy Ryder even entertained a proposal to set up an ILO Tribunal to those ends (ILO, 2011). The latter example demonstrates that while the ILO is actively engaged in major processes of global governance, the organisation is playing a secondary, supportive role, even when the issues in question are part of its constitutional mandate.

\subsection{Operational Public-Private Partnerships}

The shift towards partnerships by the ILO is consistent with the general trend towards a growing number of transnational, public-private governance initiatives (Abbott and Snidal, 2009; Andonova, 2017). The transversal nature of the issue of social justice has prompted the ILO to take a leadership role in many multi-stakeholder initiatives. One example is the ILo's leading role in Alliance 8.7, a new multi-actor initiative that seeks to eradicate forced labour, modern slavery, human trafficking and child labour in line with the UN Sustainable Development Goals. The ILO's response to the 2013 Rana Plaza factory disaster and its involvement in the governance of the resulting Accord on Fire and Building Safety in Bangladesh has highlighted the organisation's ability to work outside of traditional modalities and in greater direct contact with companies and other actors. ${ }^{19}$

16 Among the G2o Research Group's 27 mutually exclusive coded categories, the 'labour \& employment' category was the seventh most prevalent category of commitment (92), after: macroeconomic policy (375), development (179), financial regulation (154), trade (111), reform of international financial institutions (115), and energy (98).

17 An example of a commitment to ILO standards is: 'To assure that global growth is broadly beneficial, we should implement policies consistent with ILO fundamental principles and rights at work' (G2o Research Group (2015), under 'Putting Quality Jobs at the Heart of the Recovery').

18 An example of a reference to the ILO in a supporting role is: 'We recognize successful employment and training programmes are often designed together with employers and workers, and we call on the ILO, in partnership with other organizations, to convene its constituents and NGOs to develop a training strategy for our consideration' (G2o Research Group (2015), under 'Putting Quality Jobs at the Heart of the Recovery').

19 An ILO representative serves as the Independent Chair of the Steering Committee for the Accord, an independent and legally binding agreement between leading apparel brands and trade unions to improve safety in Bangladesh factories; available at: http://bangladeshaccord.org/ (accessed on 17 August 2018). 
Operationally, partnerships play an important role in the ILO's development activities (ILO, 2016c), as also highlighted by Alenda-Demoutiez et al. in this volume (Chapter 6). During the period 2008-15, the ILO entered into 243 partnerships, involving private sector firms ( 56 per cent), foundations ( 17 per cent), academia (13 per cent) and NGOs (9.5 per cent). ${ }^{20}$ The plethora of partnerships varies in terms of their objectives, including: project implementation and development, funding, advocacy, knowledge exchange, or simply organising meetings or events. Nevertheless, all partnerships in which the ILO is engaged are informed by the Director General's Announcement and Office Procedure of 2009, which requires that all partnerships must: (1) conform to ILO principles and values (as contained in the ILO's various Declarations); (2) promote the Decent Work Agenda; (3) foster tripartism (harkening back to the institution's core organising structure); (4) assure accountability; (5) promote sustainability; (6) guarantee impartiality; and (7) ensure non-preferential treatment.

The ILO's engagement in global partnerships, whatever their form, constitutes a form of institutional layering because partnerships introduce new actors into the implementation - and to a lesser extent the formulation - of governance objectives. Yet the ILO's formal institutional structures-for example, tripartism-remain firmly in place and limit to some extent the degree to which the organisation can engage with external non-state actors. This has not been the case with the ILO's global engagements with other international organisations, which are explicitly mandated by its Constitution (ILO, 2008b).

\subsection{The Limits to Partnerships and Tripartism}

The ILO's recent strategy of partnering with non-state actors-beyond the tripartite actors-was partially influenced by former UN Secretary General Kofi Annan's UN reform agenda, which called for greater engagement with the private sector and civil society and their increased involvement as 'shapers of policy' (ILO, 1998a).

The ILO has recognised on many occasions that globalisation and changing employment structures are altering the roles of public and private actors. But the tripartite actors continue to be wary of including external 'private entities' more substantively as shapers of policy, fearing that their own traditional influence could be undermined (ILO, 2008b). A strong proponent of opening up to civil society, former Director General Somavía was not concerned that including other voices would 'change the balance of the ILO' and had to reassure

20 For details, see the website http://www.ilo.org/pardev/public-private-partnerships/ WCMS_456482/lang--en/index.htm (accessed on 15 June 2018). 
his core constituents that the ILO's tripartite decision-making processes would not be diluted (ILO, 2001).

Despite extensive discussions at different points over the past two decades or more, the social partners (employers and unions) have 'used their institutional prerogatives as voting members of the ILO's legislative and executive organs to block further attempts' (Baccaro, 2015, 284) to adapt the tripartite governance model to respond better to the realities of today's world. Employers and workers agreed in 2002 on the Resolution on Tripartism and Social Dialogue, which formally reaffirmed the traditional structure of the ILO. Moreover, the social partners were to be consulted every time the Secretariat planned to work with civil society going forward (Baccaro and Mele, 2012).

Presently critics see the composition of the ILO's tripartite governance system as being unrepresentative of key constituents. Growing criticisms contend that ILO tripartism only reflects the formal economy, thereby largely leaving out the voices and concerns of those in the vast and growing informal economy, especially in developing nations (Standing, 2008). With trade union membership on the decline in many countries and large numbers of companies not affiliated with their national employer groups, the representativeness of these organisations is now questioned, leading to calls for wider perspectives in setting ILO priorities (Rodgers et al., 2009, 17).

The ILO Secretariat has managed to circumvent the resistance to broadening representativeness to a certain extent through institutional layering by engaging non-state actors strategically and less formally where appropriate. For example, staff at the International Labour Office worked on issues related to the informal sector 'if not in open defiance certainly in open non-compliance' (Bangasser, 2000, 27-28) with the preferences of the tripartite actors, who were threatened by the very existence of a sizable informal sector. When the Decent Work Agenda broadened the regulatory scope of the ILO to include non-organised labour, the non-state actors that the ILO usually engages with-employers and unions - had no incentive to promote the interests of this constituency (Helfer, 2006, 718, footnote 308). As a result, the Secretariat partnered with other civil society actors to reach informal workers, actors that eventually played a more prominent role in shaping substantive policies related to the Decent Work Agenda as well as the Agenda's implementation (Helfer, 2006, 719).

\section{5 Decentralised Governance of Labour Standards}

During the early years of the ILO, the organisation was the preeminent actor in the global governance of labour issues. Through the development of formal 
and largely non-negotiable standards, the ILO attempted to harmonise global labour standards to the greatest extent possible. Partly in response to criticisms regarding a lack of effective enforcement of labour standards globally, the ILO today is considerably more open to how decentralised governance mechanisms could help encourage greater adherence to international labour standards in a changing global economy.

Decentralised governance is based on actors coordinating their behaviour in a voluntary, ad hoc, networked and often competitive fashion, which can lead to approximation to certain standards (Lavenex and Schimmelfennig, 2009). Such 'private' modes of governance can emerge spontaneously (and may be institutionalised thereafter) or they can be developed at the initiative of a 'public' entity (Aoki, 2001). The ILO has become more open to decentralised governance mechanisms in order to promote labour standards, without replacing its traditional governance methods or relinquishing its standardsetting role. The following sections provide illustrative examples of the ILO's efforts in this regard.

\subsection{Governance by Data}

A High Level Panel appointed by the UN Secretary General to advise on the post-2015 global development agenda recommended that governments, international agencies, civil society and the private sector should work together to harness the 'data revolution' to help governments track progress and make their decisions more accountable (UN, 2015). As part of the 2030 Agenda for Sustainable Development, the ILO is making a concerted effort to boost measurement and statistics to advance its Decent Work Agenda.

It should be recalled that following the launch of the Decent Work Agenda a major effort was made to develop a composite index to measure labour conditions comparatively across countries, inspired by the widely referenced Human Development Index. Despite past failures to set up a global labour standards index, over recent years there has been a gradual shift towards more systematic measurement within the ILO. The 2013 launch of ILOSTAT, ${ }^{21}$ which provides key indicators on the labour market, builds on an earlier attempt at global governance by data. Contained within ILOSTAT are the Key Indicators of the Labour Market (KILM), first published in 1999 to provide a core set of labour market indicators to inform the ILO's technical assistance priorities. In its current form, the KILM also draws on data reported by countries by incorporating

21 ILOSTAT is the ILO'S centralised statistics database of labour market statistics for over 200 countries and over 100 indicators. See https://www.ilo.org/ilostat (accessed on 17 August 2018). 
data from other organisations, such as the United Nations Educational, Scientific and Cultural Organization (UnesCo), the Organisation for Economic Co-operation and Development (OECD) and the World Bank.

In its promulgation of indicators, the ILO can be viewed as using data to govern indirectly, because indicators can have a regulatory effect when implemented nationally (Davis et al., 2012). However, its efforts have been circumscribed. ILO constituents have not been able to agree on a common framework for measurement that would serve as a basis for comparisons globally. Establishing a social label would have been a major institutional development had it succeeded because it would have amounted to regulatory competition-as opposed to governance by steering - assuming that a global league table of labour standards implementation would result in social pressure and a competitive race to the top.

Instead, the ILO's efforts further indicate an incremental form of adaptation through the KILM, with a continuing emphasis on data and measurement. The fact that the ILO relies on data self-reported by governments and other IOs suggests that it aggregates data more than it governs by it, although the aggregation itself can perform a governing function. And while subscribing to the motto of 'what gets measured gets improved' can help improve accountability with regard to protecting labour standards globally, over reliance on the quantification of performance in general can also lead to perverse consequences such as distorted priorities and a focus on the quantity rather than the quality of standards (Biersteker, 2016).

\subsection{Governance by Best Practices}

During his tenure (1989-99), Director General Michel Hansenne considered the ILO's governance model too 'vertical' and encouraged 'horizontal' dynamics between states as a better way to promote labour standards. Hansenne advocated for developing a social label-effectively certifying governments based on their labour practices (through a Convention no less) - to give 'an impulse and force to the ILO's standard-setting action beyond its normal audience' (ILO, 1997a). The proposal, which ultimately failed, only had one strong constituency within the ILO: workers' organisations (ILO, 1997e). Several employers' organisations expressed their reservations, while many countries were sceptical largely because they considered it to be a way of reintroducing the 'social clause' in trade and thus serving as a proxy for protectionism (ILO, $1997 \mathrm{~b})$.

Hansenne's successor, Juan Somavía, was likewise committed to ensuring that the ILO, 'project its values, concerns and objectives in a wider arena' 
(ILO, 1999). To accomplish this, Somavia favoured closer collaboration with existing private and voluntary governance initiatives. Part of the reason for this was the concern that external actors that lacked sufficient expertise would begin to interpret and apply ILO standards incorrectly in their private initiatives (ILO, 2001). Rather than steer, there was a perceived need for the ILO to move those external initiatives in line with the ILo's existing norms and standards.

Throughout the first decade of the new millennium, the ILO increased its involvement in corporate social responsibility (CSR) related initiatives, for example through its role in the UN Secretary General's Global Compact initiative. CSR is driven in part by elements of regulatory competition, such as companies learning through the sharing of experiences to 'build a common understanding of social responsibility in competitive markets' (ILO, 2008a, 38). The ILo has generally promoted the principles contained in the Tripartite declaration of principles concerning multinational enterprises and social policy (MNE Declaration ${ }^{22}$ ) as the basis for good CSR practices. References to the 1998 Declaration have also been incorporated into a significant number of other non-binding standards that apply directly to the performance of companies, such as the UN Guiding Principles on Business and Human Rights, the OECD Guidelines for Multinational Enterprises ${ }^{23}$ and the Iso 26000 Social Responsibility Standard. It is also noteworthy that international framework agreements between trade unions and multinational enterprises have become a common tool for incorporating core labour standards directly into the operations of major corporate actors globally (ILO, 2007).

Relying on non-binding and decentralised mechanisms when engaging with multinational corporations might be a more effective means by which to improve working conditions at the national level compared to relying solely on traditional interstate conventions. Establishing cross-supply-chain standards that require suppliers to ensure minimum labour standards can potentially affect more workers more efficiently, circumventing the traditional channel whereby a government first ratifies and then implements relevant ILO conventions. However, such frameworks can result in the context-dependent and uneven application of labour standards, which highlights the need for more active engagement by the ILO.

22 See mNE Declaration, available at the website https://www.ilo.org/empent/Publications/ WCMS_094386/lang--en/index.htm (accessed on 21 August 2018).

23 The OECD Guidelines for Multinational Enterprises have been revised to better align with the language of the ILo Tripartite Declaration on MNEs, the Decent Work Agenda and the 1998 Declaration. See Servais and Van Goethem (2016). 
To help with global supply chain management, the ILO has already partnered with stakeholders in technical cooperation projects such as its Programme of Action for Asia and the Garment Sector in Cambodia. In 2009, the ILO established a Helpdesk for Business on International Labour Standards to advise companies seeking information on how to ensure their supply chains and procurement operations were consistent with such standards. More recently, the ILO has taken a leading role in the global discussion on how to ensure labour protection in increasingly complex supply chains, especially where governments have limited capacity to enforce compliance. The ILO is developing a programme of action to address decent work in global supply chains that combines many elements of governance raised in this chapter. The programme will be consistent with the ILO's existing instruments (various declarations) and it calls on the ILO to be 'at the centre of the global effort' (ILO, 2016a, 5-6), which will include developing partnership platforms with other international actors and partnerships to bolster the capacity of tripartite constituents at the national level.

The ILO views the increasing number of voluntary codes developing outside its structures-particularly those that invoke the ILO's values and standardsas possible stepping stones that can support further standard-setting activities (ILO, 1998b). In other words, these supplementary institutional layers do not contradict (and may augment) the ILO's formal ways of doing business. Directors General have consistently called for greater ILO engagement with such initiatives over the last two decades and this engagement has taken the form of providing information to companies or of promoting ILO standards in external private initiatives. When successful, such efforts help to broaden the scope of the ILO's regulatory reach while at the same time avoiding explicit challenges to ILO standards.

The extent to which the ILO is able to shape existing private governance arrangements is questionable. Even if it had the means to do so, the UN's Guidelines on Cooperation with the Business Sector specify that nothing in such partnerships 'shall be deemed to establish either party as the agent of the other party' (UN, 2009, 2), reinforcing the decentralised nature of the guidelines. The ILO's efforts have also been met with some scepticism, in part because CSR campaigns are sometimes no more than PR activities run by profit-seeking corporations, and because workers are third-party beneficiaries of CSR programmes (Lichtenstein, 2016). Where the ILO can have potentially more traction in decentralised governance, however, is when it takes a leadership role in an emerging policy issue, like its recent efforts in regulating global supply chains. 
Organisations require routine maintenance to remain effective and legitimate. This chapter has highlighted the ILO's recent attempts to do this across three dimensions of global governance. The organisation is increasingly reliant on non-binding standards to make labour protection more palatable, although legal instruments and the enforcement of states' obligations remain central to its mandate. It is engaging with an ever more diverse range of actors beyond its tripartite structure in order to reach its objectives. And its involvement in decentralised mechanisms for coordinating the behaviours of its constituents and external actors is an attempt to increase the ILO's regulatory reach.

Each of the ILO's efforts is an outcome of a compromise: a changing economic, social and political environment has incentivised some actors to push for change while an institutional legacy has contributed to the traditional tripartite actors perpetuating the institutional status quo. The resulting additional institutional layers of actors, rules, and mechanisms do not replicate-nor do they replace-the ILO's existing structures. Change has been incremental and in some instances insufficient to address broader global governance gaps in the areas of work and labour rights protection. As a strategy of adaptation, institutional layering has shown itself to be a viable short-term option. Over time, however, incremental adjustments can accumulate and lead to a disjuncture between formal rules and actual practices, which could incentivise further and more substantial change.

Having coexisting and potentially diverging institutional layers in place makes agency paramount, as actors will select the institutional forum-be it formal or informal —in which their interests will be best represented. The ILO's current lack of representativeness in its decision-making processes is therefore untenable in the long run. Priority needs to be given to incorporating the voices of workers and employers from the informal sector. By the ILO's own estimates, the informal economy comprises more than half of the global labour force and over 90 per cent of micro- and small enterprises worldwide. ${ }^{24}$ The informal sector is also associated with higher occurrences of abuse of workers' rights and insufficient social protection (that is to say, the area in which the organisation is most needed in today's world).

The trepidation of unions and employers' associations about broadening their representativeness, combined with the diversity of the informal sector

24 See more details at the website http://www.ilo.org/global/topics/employment-promotion/informal-economy/lang--en/index.htm (accessed on 12 June 2018). 
itself, makes it difficult to institutionalise a form of collective organisation of informal actors that could be directly represented at the ILO (Lindel, 2011). However, broadening the number and type of non-governmental organisations with consultative status with the ILO that can represent the informal sector would be a starting point. ${ }^{25}$ It would afford more actors the ability to contribute to discussions of the ILO's governance objectives. Perhaps more importantly, it could help promote compliance with international labour standards, because actors with consultative status can trigger the ILO's supervisory apparatus for certain violations. ${ }^{26}$

Recent decades have seen more attention paid to 'bottom-up' and flexible international agreements such as the Paris Climate Agreement and agreements with greater scope for active engagement by outside actors including business and civil society. Indications are that this trend will continue. The ILO appears to have traded some of the depth of its regulatory reach in return for an expanded breadth of outreach, as can be seen in its recent activities and in increasing references to its standards in public, private, and hybrid global governance arrangements. However, instruments like declarations, and in particular autonomous recommendations, are a means by which to fill gaps in the ILO's standard setting, as shown by the recent Transition from the Informal to the Formal Economy Recommendation. They can help build consensus gradually on contested issues (e.g. what constitutes the 'informal economy' and how to address it) and serve as a stepping stone to formal standard setting.

While the instruments being promoted might be non-binding in strictly legal terms, they nevertheless are standards of expected performance applying to all actors, and the global governance structures through which they are promoted are not necessarily any less important or authoritative than in previous periods. The ILO is promoting newer instruments through less formal governance structures (e.g. the G20) and more traditional arrangements (see Figure 5.3). The ILO needs to build its role as an advocate for core labour standards

25 At the time of writing, the following non-governmental regional and international organisations have consultative status with the ILO: the International Co-operative Alliance, the International Organisation of Employers, the International Trade Union Confederation, the Organization of African Trade Union Unity, Business Africa, and the World Federation of Trade Unions.

26 For example, the Committee on Freedom of Association (CFA) reviews complaints of violations to collective bargaining and freedom of association raised by governments, employers' and workers' organisations and other international organisations with ILO consultative status. 
further, prioritising engagement with willing coalition partners. As sufficient trust develops among partners, their commitments can crystallise over time into more formalised standards, norms, and implementation systems on specific issues. History shows that many formal institutions have informal beginnings, suggesting a potential to augment the ILO's future standard-setting and governance roles.

The ILO's increasing engagement in PPPs indicates that a significant range of partners are willing to play by the ILO's rules to leverage both its legitimacy as a standard setter and its wealth of expertise in supporting technical assistance to implement those standards on the ground. Globally, its engagement with the G2o and Bretton Woods Institutions shows that the ILO remains for many largely in a supporting role. A channel for greater influence would be to re-establish itself as a leading knowledge agency, using its investment in data collection to make inputs to inform major global policy processes. This might, however, require additional financial and human resources in order to compete in the research and knowledge space. For the time being the ILO's comparative advantage may remain in targeting implementation as a predominantly technical assistance agency.

Part of that role should include dedicated ILO efforts in shaping the form and content of private governance initiatives in the areas of decent work and labour rights' protection, which are growing in importance given the limits of public regulation. Interested actors are already engaging in self-regulation, as demonstrated by proliferating CSR initiatives in a wide range of industryspecific and geographically focused areas. The ILO, on its own or in cooperation with government authorities supported through technical assistance, can reinforce desirable private initiatives to make them more responsive to labour related concerns (Locke, 2013). As the ILO's own history suggests, getting in at the ground level of institutionalisation can have important and lasting effects.

The fact remains that major policy challenges remain largely unresolved and call out for effective global leadership. Guy Ryder made a bold claim for the ILO's mandate and its role in such leadership on labour issues in his statement as a candidate for the post of Director General: 'The stability of our societies, the sustainability of the global system which binds them ever more closely, and ultimately peace itself depend on its realization' $(2012,1)$.

The ILO needs to continue to evolve to fulfil that ambitious leadership role. This will require strong leadership within the ILO itself, and an acceptance that the ILO cannot lead the global policy agenda in this important issue domain on its own. 


\section{Acknowledgements}

This research is funded by the SNSF project 'Can an international organisation's propensity to reform help its member-states break through policy gridlock?'.

\section{References}

Abbott, K.W. and D. Snidal (2009) 'The Governance Triangle: Regulatory Standards Institutions and the Shadow of the State', in W. Mattli and N. Woods (eds.) The Politics of Global Regulation (Princeton: Princeton University Press).

Abbott, K.W., R.O. Keohane, A. Moravcsik, A.M. Slaughter and D. Snidal (2000) 'The Concept of Legalization', International Organization, 53(3), pp. 401-419.

Alston, P. (2005) 'Facing Up to the Complexities of the ILO's Core Labour Standards Agenda', European Journal of International Law, 16(3), pp. 467-48o, DOI: 10.1093/ ejil/chi126.

Andonova, L. (2017) Governance Entrepreneurs: International Organizations and the Rise of Global Public-Private Partnerships (Cambridge: Cambridge University Press).

Anner, M. and T. Caraway (2010) 'International Institutions and Workers' Rights: Between Labor Standards and Market Flexibility', Studies in Comparative International Development, 45(2), pp. 151-169, DOI: 10.1007/s12116-010-9064-x.

Aoki, M. (2001) Toward A Comparative Institutional Analysis (London: MIT Press).

Baccaro, L. (2015) 'Orchestration for the "Social Partners" Only: Internal Constraints on the ILO', in K. Abbott et al. (eds.) International Organizations as Orchestrators (Cambridge: Cambridge University Press).

Baccaro, L. and V. Mele (2012) 'Pathology of Path Dependency? The ILO and the Challenge of New Governance', ILR Review, 65(2), pp. 195-224, DOI: 10.1177/ 001979391206500201.

Bangasser, P.E. (2000) The ILO and the informal sector: an institutional history (Geneva: ILO).

Biersteker, T. (2016) 'Self - Assessment Reviews and External Evaluation Exercises in IR Education', International Studies Review, 18(2), pp. 341-345.

Biersteker, T. (2015) 'Global Governance', in R. Rotberg (ed.) On Governance: National and International Dimensions of Measuring Governance Effectiveness (Waterloo Ontario: CIGI).

Biersteker, T. (1998) 'Globalization and the Modes of Operation of Major Institutional Actors', OxfordDevelopment Studies, 26(1), pp.15-31, DOI:10.1080/13600819808424143. Biffl, G. and J.E. Isaac (2002) How Effective are the ILO's Labour Standards under Globalisation?, WIFO Working Papers, No. 178, pp. 1-34. 
Blanton, R.G., S.L. Blanton and D. Peksen (2015) 'The Impact of IMF and World Bank Programs on Labor Rights', Political Research Quarterly, 68(2), pp. 324-336, DOI: $10.1177 / 1065912915578462$.

Boockmann, B. (2001) 'The Ratification of ILO Conventions: A Hazard Rate Analysis', Economics and Politics, 13(3), pp. 281-309, DOI: 10.1111/1468-0343.00094.

Davis, K.E., B. Kingsbury and S.E. Merry (2012) 'Indicators as a Technology of Global Governance', Law \& Society Review, 46(1), pp. 71-104, DOI:10.1111/j.1540-5893.2012.00473.x.

G2o Research Group (2015) G2o Summit Commitments by Issue: 2008 to 2015, Munk School of Global Affairs, University of Toronto, http://www.g20.utoronto.ca/ compliance/commitments.html (accessed 5 August 2017).

Haworth, N. and S. Hughes (1997) 'Trade and International Labour Standards: Issues and Debates over a Social Clause', Journal of Industrial Relations, 39(2), pp. 179-195, DOI: $10.1177 / 002218569703900201$.

Helfer, L. (2006) 'Understanding Change in International Organizations: Globalization and Innovation in the ILO', Vanderbilt Law Review, 59(3), pp. 649-726.

Hughes, S. and N. Haworth (2011) The International Labour Organization: Coming in from the Cold (Oxon, UK: Routledge).

ILO (International Labour Organisation) (2018a) Resolutions adopted by the International Labour Conference, https:/www.ilo.org/global/about-the-ilo/how-the-iloworks/departments-and-offices/jur/legal-instruments/WCMS_42859o/lang--en/ index.htm (accessed on 21 August 2018).

ILO (2018b) ILO Declarations, https://www.ilo.org/global/about-the-ilo/how-the-iloworks/departments-and-offices/jur/legal-instruments/WCMS_428589/lang--en/ index.htm (accessed on 21 August 2018).

ILO (2018c) Recommendations, https://www.ilo.org/dyn/normlex/en/f?p=1000:12010::: NO::: (accessed on 21 August 2018).

ILO (2018d) Conventions, https://www.ilo.org/dyn/normlex/en/f?p=NORMLEXPUB: 12000:0::NO::: (accessed on 21 August 2018).

ILO (2018e) ILO cooperation agreements with other international organizations, http:// www.ilo.org/global/about-the-ilo/how-the-ilo-works/departments-and-offices/ jur/legal-instruments/WCMS_442247/lang--en/index.htm (accessed on 21 August 2018).

ILO (2016a) Studies on Growth and Equity: Assessment of Labour Provisions in Trade and Investment Arrangements (Geneva: ILO), https://www.ilo.org/wcmsp5/groups/ public/---dgreports/---inst/documents/publication/wcms_498944.pdf (accessed on 21 August 2018).

ILO (2016b) Labour-related provisions in trade agreements: Recent trends and relevance to the ILO (Geneva:ILO), https://www.ilo.org/wcmsp5/groups/public/---ed_norm/--relconf/documents/meetingdocument/wcms_530526.pdf (accessed on 21 August 2018). 
ILO (2016c) Report of the Director General: ILO Programme Implementation, 2014-2015 (Geneva: ILO), https:/www.ilo.org/ilc/ILCSessions/105/reports/reports-to-theconference/WCMS_473667/lang--en/index.htm (accessed on 21 August 2018).

ILO (2013) Report of the Director General: Towards the ILO Centenary (Geneva: ILO), http://www.ilo.org/wcmsp5/groups/public/---ed_norm/---relconf/documents/ meetingdocument/wcms_213836.pdf (accessed on 21 August 2018).

ILO (2012) Governing Body 316 th Session:Agenda of the International Labour Conference (Geneva: ILO), https://www.ilo.org/wcmsp5/groups/public/---ed_norm/---relconf/ documents/meetingdocument/wcms_192447.pdf (accessed on 22 August 2018).

ILO (2011) Report of the Director General: A New Era of Social Justice (Geneva: ILO), https://www.ilo.org/wcmsp5/groups/public/---ed_norm/---relconf/documents/ meetingdocument/wcms_155656.pdf (accessed on 21 August 2018).

ILO (2009) Report of the Director-General: Tackling the global jobs crisis: Recovery through decent work policies (Geneva: ILO), https:/www.ilo.org/wcmsp5/groups/ public/---ed_norm/---relconf/documents/meetingdocument/wcms_106162.pdf (accessed on 21 August 2018).

ILO (2008a) Report of the Director-General: Freedom of association in practice: Lessons Learned (Geneva: ILO), http://www.ilo.org/wcmsp5/groups/public/---dgreports/--dcomm/documents/publication/wcms_096122.pdf (accessed on 21 August 2018).

ILO (2008b) Report of the Committee on Strengthening the ILO's Capacity: Strengthening the ILO's capacity to assist its Members' efforts to reach its objectives in the context of globalization (Geneva: ILO), http://www.ilo.org/ilc/ILCSessions/97thSession/pr/ WCMS_094005/lang--en/index.htm (accessed on 21 August 2018).

ILO (2007) International Framework Agreements: a global tool for supporting rights at work, http://www.ilo.org/global/about-the-ilo/newsroom/news/WCMS_080723/ lang--en/index.htm (accessed on 21 August 2018).

ILO (2001) Provisional Record: Reply by the Director-General to the discussion of his Report (Geneva: ILO), http://www.ilo.org/public/english/standards/relm/ilc/ilc89/ pdf/pr-20.pdf (accessed on 21 August 2018).

ILO (1999) Decent Work, Report of the Director-General (Geneva: ILO), http://www.ilo .org/public/english/standards/relm/ilc/ilc87/rep-i.htm (accessed on 27 July 2017).

ILO (1998a) Developments in the United Nations in 1997-98 (Geneva: ILO), http://www .ilo.org/public/english/standards/relm/gb/docs/gb271/gb-8-1.htm (accessed on 21 August 2018).

ILO (1998b) Preliminary consultation on the Programme and Budget proposals for 200o2001 (Geneva: ILO), http://www.ilo.org/public/english/standards/relm/gb/docs/ gb271/gb-5.htm (accessed on 21 August 2018).

ILO (1997a) The ILO, Standard Setting and Globalization, Report of the Director General (Geneva: ILO), http://www.ilo.org/public/english/standards/relm/ilc/ilc85/dg-rep .htm (accessed on 22 August 2018). 
ILO (1997b) Follow-up on the discussion of the Report of the Director-General to the 85th Session (1997) of the International Labour Conference, GB.270/3/2 (Geneva: ILO), http://www.ilo.org/public/english/standards/relm/gb/docs/gb270/gb-3-2.htm (accessed on 21 August 2018).

ILO (1997c) Follow-up on the discussion of the Report of the Director-General to the 85th Session (1997) of the International Labour Conference, GB.270/3/1A (Geneva: ILO), http://www.ilo.org/public/english/standards/relm/gb/docs/gb270/gb-3-1a.htm (accessed on 21 August 2018).

ILO (1997d) Follow-up on the discussion of the Report of the Director-General to the 85th Session (1997) of the International Labour Conference, GB.270/3/1 (Geneva: ILO), http://www.ilo.org/public/english/standards/relm/gb/docs/gb270/gb-3-1.htm (accessed on 21 August 2018).

ILO (1997e) Proposals for the agenda of the 88th Session (2000) of the International Labour Conference: Draft portfolio (Geneva: ILO), http://www.ilo.org/public/english/ standards/relm/gb/refs/rodp270.htm\#Proposals\%2ofor\%2othe\%2oagenda\% 200f\%20the\%2088th\%2oSession\%20(2 (accessed on 21 August 2018).

Lavenex, S. and F. Schimmelfennig (2009) 'EU Rules Beyond EU Borders: Theorizing External Governance in European Politics', Journal of European Public Policy, 16(6), pp. 791-812, DOI: 10.1080/13501760903087696.

Lichtenstein, N. (2016) 'The Demise of Tripartite Governance and the Rise of the Corporate Social Responsibility Regime', in R.P. Appelbaum and N. Lichtenstein (eds.) Achieving Workers' Rights in the Global Economy (Ithaca, NY: Cornell University Press).

Lindell, I. (2011) 'Introduction to the Special Issue: Organizing across the formal-informal worker constituencies', Labour, Capital and Society, 44(1), pp. 2-16.

Locke, R. (2013) The Promise and Limits of Private Power: Promoting Labor Standards in a Global Economy (Cambridge, UK: Cambridge University Press).

Mahoney, J. (2000) 'Path Dependence in Historical Sociology', Theory and Society, 29(4), pp. 507-548, https://www.jstor.org/stable/3108585.

Mahoney, J. and H. Thelen (2010) 'A Theory of Gradual Institutional Change' in J. Mahoney and H. Thelen (eds.) Explaining Institutional Change: Ambiguity, Agency, and Power (Cambridge, UK: Cambridge University Press).

Onida, F. (2008) Labour standards and the ILO's effectiveness in the governance of globalization, KITes Working Papers 218, KITeS, Centre for Knowledge, Internationalization and Technology Studies, Universita' Bocconi, Milan, ftp://ftp.unibocconi.it/ pub/RePEc/cri/papers/WP218Onida.pdf (accessed on 21 August 2018).

Pierson, P. (2004) Politics in Time: History, Institutions, and Social Analysis (Princeton: Princeton University Press).

Rodgers, G., E. Lee, L. Swepston and J. Van Daele (2009) The International Labour Organization and the Quest for Social Justice (Ithaca, NY: Cornell University Press). 
Ryder, G. (2012) The ILO: A vision statement by Guy Ryder, candidate for the post of Director-General (Geneva: ILO), http://www.ilo.org/gb/about-governing-body/ appointment-of-director-general/WCMS_175250/lang--en/index.htm (accessed on 2 August 2017).

Servais, J.M. and V. Van Goethem (2016) International Labour Organization (ILO), Second Edition (Alphen aan den Rijn: Kluwer Law International).

Somavia, J. (2008) After the Meltdown:Advancing Living Standards around the Globe in the Wake of the Financial Crisis (Washington, D.C.: ILO), http://www.ilo.org/global/ about-the-ilo/newsroom/statements-and-speeches/WCMS_101078/lang--en/index .htm (accessed on 28 August 2017).

Standing, G. (2010) 'The International Labour Organization', New Political Economy, 15(2), pp. 307-318, DOI: 10.108o/13563460903290961.

Standing, G. (2008) 'The ILO: An Agency for Globalization?' Development and Change, 39(3), pp. 355-384, DOI: 10.1111/j.1467-7660.2008.00484.x.

Vabulas, F. and D. Snidal (2013) 'Organization without delegation: Informal intergovernmental organizations (IIGOs) and the spectrum of intergovernmental arrangements', Review of International Organizations, 8, pp. 193-220.

UN (United Nations) (2015) A New Global Partnership: Eradicate Poverty and Transform Economies Through Sustainable Development - The Report of the High-Level Panel of Eminent Persons on the Post-2015 Development Agenda, https://www.un.org/sg/sites/ www.un.org.sg/files/files/HLP_P2015_Report.pdf (accessed on 21 August 2018).

UN (2009) Guidelines on Cooperation between the United Nations and the Business Sector (New York: UN), http://www.un.org/ar/business/pdf/Guidelines_on_ UN_Business_Cooperation.pdf (accessed on 23 August 2018).

Weiss, T.G. (2011) 'Foreword', in S. Hughes and N. Haworth (eds.) The International Labour Organization: Coming in from the Cold (Oxon, UK: Routledge).

WTO (World Trade Organization) (2018) Regional Trade Agreements Information System (RTA-IS), https://rtais.wto.org/UI/PublicMaintainRTAHome.aspx (accessed on 21 August 2018). 